\title{
A Late Silurian (Pridolian) age for the Eastport Formation, Maine: a review of the fossil, stratigraphic, and radiometric-age data
}

\author{
Lisa Churchill-Dickson \\ Maine State Museum, 83 State House Station, Augusta, ME 04333-0083, USA, \\ <paleo@gwi.net>
}

Date received:May 17, 2004 Date accepted:August 24, 2004

\begin{abstract}
The Eastport Formation is part of a larger volcaniclastic sequence (the Coastal Volcanic Belt) that extends from Massachusetts, USA, into New Brunswick, Canada. It represents a portion of Avalonia that was accreted to Laurentia during the Acadian orogeny. For more than thirty years the age of this formation has been regarded as Early Devonian (Lochkovian or Pragian) based on a new and yet undescribed ostracode genus. However, careful analysis of the fossil data indicates a Late Silurian (Pridolian) age for the fauna, and shows that the evidence used to assign a Devonian age should have been regarded as provisional. This interpretation is additionally strengthened by local stratigraphy and recent radiometric dating, both of which support a Late Silurian age for the Eastport Formation.
\end{abstract}

\section{RÉSUMÉ}

La Formation d'Eastport fait partie d'une séquence volcanoclastique plus importante (ceinture volcanique Côtière) qui s'étend du Massachusetts, aux États-Unis, jusqu'à l'intérieur du Nouveau-Brunswick, au Canada. Elle représente une partie du continent avalonien qui s'était accrétionné au continent laurentien pendant l'orogenèse acadienne. Pendant plus d'une trentaine d'années, on a considéré que cette formation remontait au Dévonien précoce (Lochkovien ou Praguien) en se basant sur un nouveau genre d'ostracode encore non décrit. Une analyse attentive des données relatives au fossile révèle toutefois que la faune remonte au Silurien tardif (Pridolien) et montre que les observations utilisées pour l'attribution d'un âge dévonien auraient dû être considérées comme provisoires. Cette interprétation se trouve par ailleurs renforcée par la stratigraphie locale et une datation isotopique récente, qui appuient toutes deux la datation de la Formation d'Eastport à l'époque du Silurien tardif.

[Traduit par la rédaction.]

\section{INTRODUCTION}

The Eastport Formation is part of an extensive group of mid-Paleozoic volcanic and sedimentary units known collectively as the Coastal Volcanic Belt. This belt stretches from Massachusetts, through eastern Maine and into New Brunswick and represents a portion of Avalonia that was accreted to Laurentia during the Acadian orogeny (Berry and Osberg 1989; Ludman et al. 1993; Fyffe et al. 1999). The Eastport Formation represents the youngest, syntectonic unit in the Coastal Volcanic Belt. There has been significant interest in accurately dating it in an effort to better understand the dynamics of the orogeny, specifically as these dynamics relate to its overall duration (e.g., Osberg et al. 1989; Bradley et al. 2000; Tucker et al. 2001). In addition, correlation with the Eastport Formation has also been used to date the uppermost strata (Seal Cove Formation) within the North Haven and Vinalhaven volcanic sequence of the Penobscot Bay region,
Maine (Brookins et al. 1973; Gates 2001), as well as Silurian and Devonian sequences - particularly the Canadian portion of the Eastport Formation - in New Brunswick (Pickerill and Pajari 1976; Fyffe et al. 1999).

For more than thirty years, researchers have consistently cited ostracode occurrences to date the Eastport Formation of Maine as Early Devonian (e.g., Gates 1975; Berry and Osberg 1989; Bradley et al. 2000; Fyffe et al. 1999). However, a critical review of the ostracode data shows that it was never robust enough to assign a definite Devonian date to the formation, and that the age assignment should have been noted as provisional at best. In fact, a more complete analysis of the fossil and stratigraphic evidence indicates a Late Silurian, rather than a Devonian, age for the Eastport Formation. It is notable that the early authors also regarded the formation as Late Silurian based on biostratigraphic correlations with European faunas 
(Bastin and Williams 1914). Recent radiometric dating(Miller and Fyffe 2002; Van Wagoner and Dadd 2003) also support a Silurian age for the Eastport Formation.

\section{HISTORICAL WORK}

The formations of the Coastal Volcanic Belt in eastern Maine were first described by Jackson (1837) and more formally by Shaler (1886). With the prospect of potential coal-bearing beds in the area, the U. S. Geological Survey dispatched a geologist (E. S. Bastin) and paleontologist (H. S. Williams) to study the formations and their faunas in more depth. From this work, a folio of the area was produced (Bastin and Williams 1914), as well as several other publications discussing the taxonomic and biostratigraphic significance of the faunas (e.g., Williams 1912a, b; 1913).

While working with the fossils, Williams became acutely aware that the faunas more closely resembled European specimens than those from North America (Williams 1912a, b). This presented a serious conundrum for him. With the theory of plate tectonics nearly fifty years away, Williams had no way to satisfactorily explain why American faunas should more closely resemble their trans-Atlantic counterparts than those on the same continent. In fact, this apparent anomaly became so troubling to him that he devoted an entire address to it to the Geological Society of America in 1912, later published in 1913. The Eastport fauna, particularly the molluses, he correlated with the Downtonian of Great Britain, which Williams considered firmly in the Silurian (Bastin and Williams 1914; p. 10). He assigned a Late Silurian age to the Eastport Formation based on that correlation (Williams 1912a, b; Bastin and Williams 1914), an assignment that remained for nearly sixty years before being revisited.

\section{FOSSIL EVIDENCE}

\section{Ostracode data}

More than thirty years ago, both Anders Martinsson (1970) and Jean Berdan (1971) recognized a new genus of ostracode within the upper Eastport Formation. The genus was never formally described, but Berdan noted it most closely resembled forms assigned to the genus Carinokloedenia from Lochkovian age deposits of northern France and Pragian age deposits of Podolia in southwestern Ukraine (Berdan 1971, 1990; Brookins et al. 1973). Martinsson $(1970 ; 1977)$ also observed that the undescribed Eastport ostracode (cf. Carinokloedenia) bore affinities to those in Podolia, although he too noted they represented a new genus. Based on the close resemblance of the Eastport forms to the Devonian age European material, both paleontologists felt justified in assigning an Early Devonian age to the Maine unit (Martinsson 1970, 1977; Berdan 1971, 1990; Brookins et al. 1973). However, biostratigraphic correlations based on new and undescribed genera are hardly robust, no matter how closely allied to other described genera. Even if the new Eastport forms had been formally described, they would have been known only from that unit and locality - the Eastport Formation of Maine. Biostratigraphic correlations would have been precluded since the genus, although similar to other forms, was new to science and not known from any other area. At best, the age assignment should have been regarded as provisional.

More importantly, the ostracode genus Nodibeyrichia had been recovered from both the lower Eastport and underlying Hersey formations (Copeland and Berdan 1977; Berdan 1983; Siveter 1989). Nodibeyrichia is well known from Late Silurian sequences in Europe and is often considered an index fossil for that time interval (Martinsson 1970; Berdan 1971; 1990; Copeland and Berdan, 1977; Siveter 1989). In fact, Siveter (1989) assigned a Pridolian age to the basal portions of the Eastport Formation based on the presence of Nodibeyrichia.

Additionally, Carinokloedenia? forms had been found in association with Nodibeyrichia within both the Eastport and Hersey formations (Copeland and Berdan 1977; Berdan 1983; Siveter 1989; see Fig. 1, this paper). This important association should have been given considerable weight and should have called into question the Devonian assignments given to the cf. Carinokloedenia forms found higher in the Eastport sequence. Overall, the positive identification of a described genus, Nodibeyrichia, and its restriction to Silurian sequences, should have been given higher priority than the tentative assignment and unknown biostratigraphic constraints of the new, undescribed ostracode form, cf. Carinokloedenia. Furthermore, the association of Carinokloedenia? with Nodibeyrichia in the lower Eastport should have been used to extend the range of Carinokloedenia-like forms into the Late Silurian, instead of extending the range of Nodibeyrichia, a better documented and more restricted taxon, into the Early Devonian.

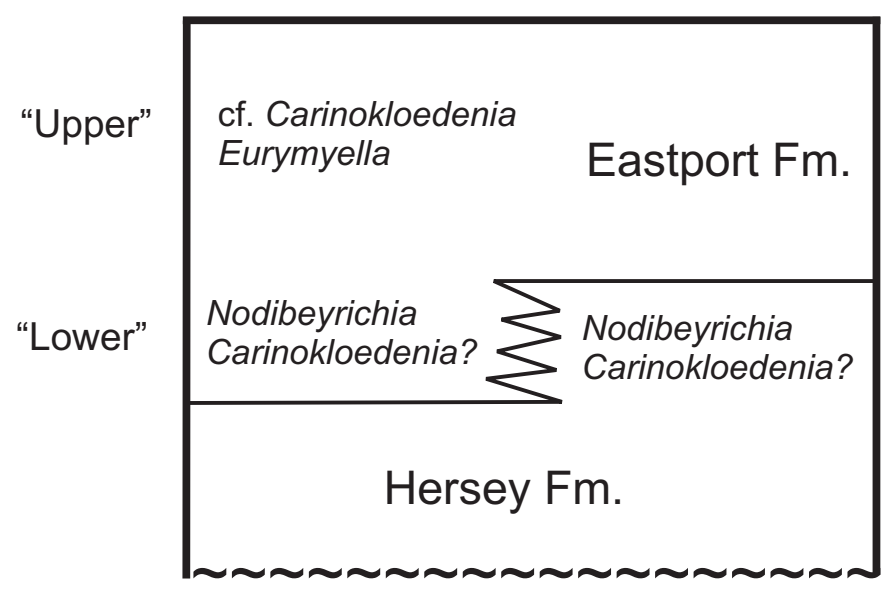

Fig. 1 Generalized column highlighting the relative position of stratigraphically significant genera within the Eastport and Hersey formations. 


\section{Other fauna}

A listing of all fossils recovered from the Eastport Formation is provided in Table 1. Overall, the low taxonomic diversity of the fauna combined with leperditid, lingulid and eurypterid specimens is suggestive of shallow marine, perhaps estuarine, conditions. Of all the other fauna described thus far from the Eastport Formation, there appears to be only one non-ostracode genus (Eurymyella) that has the potential to provide more information about its relative age.

In 1912, Williams erected the genus Eurymyella to describe the molluscs found within the upper part of the Eastport Formation (Williams 1912a). Williams considered them closely allied to Silurian age Anodontopsis angustifrons McCoy from the Downtonian Formation of Great Britain, and likely "including some of the forms" assigned to that genus (Bastin and Williams 1914). To date, eurymyellids have never been formally reported from another area. In fact, the validity of the genus itself has been in question at least since the publication of the bivalve volume of the Treatise on Invertebrate Paleontology in 1969 (Newell 1969), and is currently being reviewed by the author, in collaboration with John Pojeta (USGS-USNM). A very preliminary review by Pojeta (personal communication, 2004) indicated the possible presence of Eurymyella within collections from the Pridolian age Leighton Formation, Maine. However, additional study is needed to confirm this. At this point, the stratigraphic significance of the eurymyellid fauna cannot be judged.

The bivalve genera of Nyassa and Whiteavesia were originally identified by Williams in Smith and White (1905). They were named in a faunal listing with no accompanying graphics. Since they were never repeated in any of Williams' subsequent works, they are interpreted to represent incorrect assignments. The validity of this interpretation is strengthened by the fact that Whiteavesia is restricted to the Ordovician. The remaining faunal elements within the Eastport Formation are all known to occur within Silurian and Devonian age deposits alike and are therefore not stratigraphically useful in this context.

\section{STRATIGRAPHIC RELATIONS}

A summary of the stratigraphic relations, age assignments and supporting age data for the Coastal Volcanic Belt formations in Maine is given in Table 2. The Dennys, Edmunds, Leighton, Hersey and Eastport formations seem to represent a continuous sequence with no obvious hiatus at any of the contacts. The Quoddy and Dennys formations are separated by a fault, whereas the Perry Formation overlies the Eastport, Hersey and Leighton formations with an angular unconformity (Gates 1975).

The nature of the boundary between the Eastport and Hersey formations is gradational, and there are places where the two formations have been identified as age equivalents (Gates 1975). The Hersey Formation has been convincingly dated as Pridolian based on the presence of the ostracode
Nodibeyrichia (Martinsson 1970; Berdan 1971; 1990; Copeland and Berdan 1977; Berdan 1983; Siveter 1989). Therefore, the portions of the Eastport Formation that are known to grade into the Hersey Formation, and have been identified as age equivalents, must also be assigned a Pridolian age. While it could be argued that the units stratigraphically above the Nodibeyrichia-bearing beds within the Hersey and Eastport formations may be Devonian, there is no evidence to convincingly suggest this. Therefore, the more parsimonious approach would be to regard the entire Eastport Formation as Pridolian age until compelling evidence is found to suggest otherwise.

The Early Devonian age that is commonly assigned to the Hersey Formation is based on the fact that it interfingers with the assumed Devonian age Eastport Formation. The Hersey Formation, in addition to Nodibeyrichia, contains two undescribed ostracode taxa (Carinokloedenia? and cf. Zygobeyrichia) reminiscent of similar forms in Devonian age deposits of Podolia (Berdan 1971; Gates 1975). This brings up the concerns expressed previously about the use of undescribed species for biostratigraphic correlations. Also, as discussed previously, the presence of Nodibeyrichia (Pridolian) in both the Hersey and Eastport formations provides well-accepted Silurian constraints to the units. In view of these facts, the Devonian age designation for the Hersey formation should likewise be discontinued.

Although the formations are arranged vertically in Table 2, there is preliminary evidence to suggest that some of these units may actually represent age-equivalent facies. This is the case for the Eastport and Hersey formations, and may be the case for part of the Leighton Formation. Stratigraphic evidence includes the interfingering of the Hersey and Eastport formations and the replacement of the Hersey by the Eastport in more southerly reaches, with the Eastport Formation apparently conformably overlying the Leighton Formation (see Gates 1975). Fossil data, including the Nodibeyrichia-Carinokloedenia? association in both the Hersey and Eastport formations, and the possible presence of Eurymyella within the Leighton Formation, are also suggestive of age-equivalency among the different formations. Charlotte Mehrtens (University of Vermont) and the author are presently engaged in field work detailing the sedimentology, stratigraphy, and paleoecology of these formations in an effort to gain a better understanding of their lateral and vertical (e.g., space and time) relationships, as well as the environmental parameters active during their deposition.

\section{RADIOMETRIC DATES}

There have been several attempts to obtain radiometric dates on the Eastport Formation. Fullagar and Bottino (1970) reported an age of $408 \pm 3 \mathrm{Ma}$ for the formation based on $\mathrm{Rb}$ Sr dating of volcanics within it. They also dated a dike that cut through the Eastport and obtained an age of 400 to $420 \mathrm{Ma}$ (Fullagar and Bottino 1970).

The Red Beach pluton, which intrudes the Eastport, was dated by both $\mathrm{Rb}-\mathrm{Sr}$ and $\mathrm{U}-\mathrm{Pb}$ methods. The Rb-Sr work 
Table 1. Faunal listing for the Eastport Formation, Maine. The numbers in parentheses correspond to the references following the listing. See bibliography for full citations. Paleontological workers responsible for taxonomic identifications are listed within the references. Explanation of abbreviations used in references: B (bivalves), $\mathrm{Br}$ (brachiopods), Eu (eurypterid), F (fish), G (gastropod), $\mathrm{O}$ (ostracode) and $\mathrm{Ph}$ (phyllocarid). The brachiopod listings have been updated by A. J. Boucot (personal communication, 2001). Quotation marks indicate that the taxa are probably something other than what was originally identified.

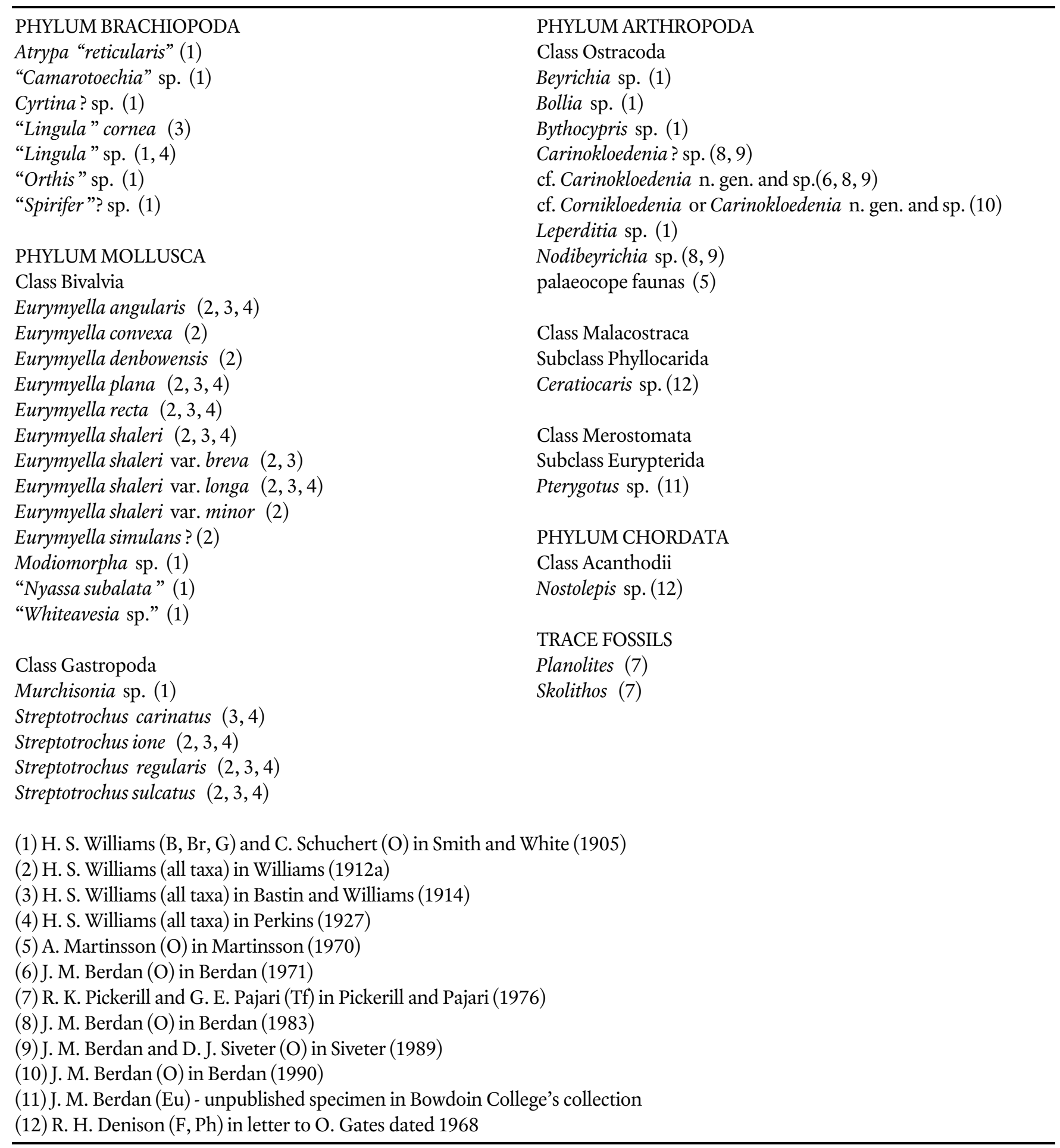


Table 2. Summary of formations within the Maine sequence of the Coastal Volcanic Belt. Age criteria are based largely on fossil evidence, although radiometric dates are also listed. The types of contacts between each set of formations, and references to that information, are also provided. Full citations are listed in reference section.

\begin{tabular}{|c|c|c|c|c|}
\hline Formation & Age & Age Criteria & Stratigraphic Relations & Radiometric Dates \\
\hline Perry & Upper Devonian & $\begin{array}{l}\text { Archaeopteris: Upper } \\
\text { Devonian (Kasper et al. 1988) }\end{array}$ & $\begin{array}{l}\text { overlies Eastport, Hersey and } \\
\text { Leighton with angular } \\
\text { unconformity (Gates 1975) }\end{array}$ & $\begin{array}{l}\text { no datable zircons found in ash } \\
\text { bed in Perry (Bradley et al. } \\
2000)\end{array}$ \\
\hline Eastport & Pridoli & $\begin{array}{l}\text { Nodibeyrichia: Pridoli (Berdan } \\
\text { 1990; Siveter 1989) }\end{array}$ & $\begin{array}{l}\text { angular unconformity } \\
\text { separating Eastport from } \\
\text { overlying Perry (Gates 1975) }\end{array}$ & $\begin{array}{l}\text { U-Pb zircon laser ablation: } 419 \\
\text { to } 436 \pm 6 \text { Ma on volcanics } \\
\text { (Van Wagoner and Dadd 2003) }\end{array}$ \\
\hline Hersey & Pridoli & $\begin{array}{l}\text { Nodibeyrichia: post-Ludlow } \\
\text { (Martinsson 1970) } \\
\text { Nodibeyrichia: Pridoli (Berdan } \\
\text { 1990; Siveter 1989) }\end{array}$ & $\begin{array}{l}\text { gradational contact with } \\
\text { Eastport; parts of Hersey and } \\
\text { Eastport are lateral equivalents } \\
\text { (Gates 1975) }\end{array}$ & \\
\hline Leighton & $\begin{array}{l}\text { Upper Ludlow to } \\
\text { Pridoli }\end{array}$ & $\begin{array}{l}\text { Neobeyrichia, Sleia, } \\
\text { Macrypsilon, Hemsiella, } \\
\text { Lophoctenella: Ludlow } \\
\text { (Martinsson 1970) } \\
\text { Calcaryibeyrichia, Hemsiella, } \\
\text { Lophoctenella, Londinia, } \\
\text { Macrypsilon, Sleia }: \text { Pridoli } \\
\text { (Berdan 1990) }\end{array}$ & $\begin{array}{l}\text { conformable boundary with } \\
\text { Hersey (Gates 1975) }\end{array}$ & \\
\hline Edmunds & Upper Ludlow & $\begin{array}{l}\text { Londinia , Lophoctenella, Sleia: } \\
\text { Upper Ludlow (Martinsson } \\
\text { 1970; Berdan 1990) }\end{array}$ & $\begin{array}{l}\text { conformable boundary with } \\
\text { Leighton (Gates 1975) }\end{array}$ & \\
\hline Dennys & $\begin{array}{l}\text { Late Llandovery } \\
\text { to Ludlow }\end{array}$ & $\begin{array}{l}\text { no zonable fossils (Berry and } \\
\text { Boucot 1970); stratigraphic } \\
\text { position }\end{array}$ & $\begin{array}{l}\text { conformable boundary with } \\
\text { Edmunds (Gates 1975) }\end{array}$ & \\
\hline Quoddy & Late Llandovery & $\begin{array}{l}\text { Monograptus cf. clintonensis, } \\
\text { M.cf. jaculum, } M . \mathrm{cf} . \\
\text { priodon, } \text { M. variabilis?, } M . \\
\text { nudus: Late Llandovery (Berry } \\
\text { and Boucot } 1970 \text { ) }\end{array}$ & $\begin{array}{l}\text { base not exposed; top is in fault } \\
\text { contact with Dennys (Gates } \\
\text { 1975) }\end{array}$ & \\
\hline
\end{tabular}

produced an age of $385 \pm 6 \mathrm{Ma}$, recalculated (Spooner and Fairbuirn 1970), while the U-Pb analysis yielded an age of $415 \pm$ $6 \mathrm{Ma}$ (Jurinski 1990). Both dates were considered highly suspect and ultimately dismissed by Bradley et al. (2000). Furthermore, Bradley et al. (2000) noted that Rb-Sr dates have consistently proven to be too young in the region, an observation that also casts considerable doubt on Fullagar and Bottino's work.

In New Brunswick, Miller and Fyffe (2002) have obtained radiometric dates from zircons in Coastal Volcanic belt units underlying the Eastport Formation. Previous analyses of these units relied heavily on the presence of the brachiopod, Salopina, to indicate a Late Silurian age (see Miller and Fyffe 2002 for discussion). However, the recent radiometric ages obtained from the volcanic rocks in those units indicated an Early Silurian (Llandoverian), rather than a Pridolian, age. From this,
Miller and Fyffe (2002) suggested that the Eastport Formation, which overlies these Llandoverian units, may in fact predate the Early Devonian. Their paper suggested a Ludlovian or Pridolian age.

Recently, there have been renewed efforts to obtain U-Pb dates of the Eastport Formation itself using laser ablation, LAM-ICPMS, methods (see Sylvester 2001 and Jackson et al. 2003 for an overview of this technique and its various applications). Van Wagoner and Dadd (2003) used this technique to date felsic tuffs and rhyolite flows within the Eastport Formation and obtained dates ranging from $419 \pm 6$ to $436 \pm$ $6 \mathrm{Ma}$. A paper describing the dating techniques, exact localities and horizons of the two units from which the dates were obtained, and their geological significance is currently in preparation (N. A. Van Wagoner, personal communication, 2004). 
Although there is definite disparity between the two dates (one places the Eastport in the Late Silurian, the other in the Early Silurian), they do suggest a firm Silurian date.

\section{CONCLUSION}

The age of the Eastport Formation has the potential to provide important information about the timing and duration of the Acadian orogeny, as well as significant information to be used in regional correlations. For over thirty years, the date of the Eastport Formation has been regarded as Early Devonian based on poorly constrained fossil data - principally the unnamed ostracode, cf. Carinokloedenia. Instead, age assignments should have been based on more robust fossil data, notably the presence of Nodibeyrichia, in addition to the stratigraphic evidence that convincingly links portions of the Eastport Formation with the Hersey Formation of known Pridolian age (Table 1). This data, combined with the recent radiometric dating and stratigraphic work of Miller and Fyffe (2002) and Van Wagoner and Dadd (2003), strongly favour a Late Silurian (Pridolian) age for the Eastport Formation over a Devonian one. A Silurian age for the Eastport Formation has important implications for regional stratigraphy and will require that previous correlations, particularly the relationship between the Seal Cove and Eastport formations, and the Maine and New Brunswick portions of the Eastport Formation, be re-examined in light of these findings.

\section{ACKNOWLEDGEMENTS}

The author is greatly indebted to A. Boucot for serving as a mentor during these past years and helping to decipher Maine's complex geological and paleontological histories. J. Pojeta and R. Blodgett have both been invaluable guides in the molluscan world. Both A. Boucot and J. Pojeta reviewed an earlier draft of the paper and made valuable critiques. Thoughtful reviews by L. Fyffe, R. Fensome and the editor, and discussions with C. Mehrtens, H. Berry, T. Dutro and S. Dickson, have likewise improved the quality of this paper.

\section{REFERENCES}

Bastin, E. S., \& Williams, H. S. 1914. Description of the Eastport Quadrangle, Maine. U. S. Geological Survey, Geologic Atlas of the United States Folio, 192, $15 \mathrm{p}$.

BERDAN, J. M. 1971. Silurian to early Devonian ostracodes of European aspect from the Eastport quadrangle, Maine. Geological Society of America Abstracts with Program, 3, No. 1, p. 18.

BERDAN, J. M. 1983. Biostratigraphy of Upper Silurian and Lower Devonian ostracodes in the United States. In Appli- cations of Ostracoda. Edited by R. F. Maddocks. University of Houston Department of Geosciences, Houston, Texas, pp. 313-337.

BERDAN, J. M. 1990. Silurian and Early Devonian biogeography of ostracodes in North America. In Palaeozoic Palaeogeography and Biogeography. Edited by W. S. McKerrow $\&$ C. R. Scotese. The Geological Society of London, pp. 223-232.

Berry, W. B. N., \& Boucot, A. J. 1970. Correlation of North American Silurian rocks. Geological Society of America Special Paper, 102, 289 p.

BERry IV, H. N., \& OsBerg, P. H. 1989. A stratigraphic synthesis of eastern Maine and western New Brunswick. In Studies in Maine Geology. Edited by R. D. Tucker and R. G. Marvinney. Maine Geological Survey, Augusta, pp. 1-32.

Bradley, D. C., Tucker, R. D., Lux, D. R., Harris, A. G., \& McGregor, D. C. 2000. Migration of the Acadian orogen and foreland basin across the northern Appalachians of Maine and adjacent areas. U.S. Geological Survey Professional Paper, 1624, 55 p.

Brookins, D. G., Berdan, J. M., \& Stewart, D. B. 1973. Isotopic and paleontologic evidence for correlating three volcanic sequences in the Maine Coastal Volcanic Belt. Geological Society of America Bulletin, 84, pp. 1619-1628.

Copeland, M. J., \& Berdan, J. M. 1977. Silurian and Early Devonian beyrichiacean ostracode provincialism in northeastern North America. Geological Survey of Canada, Paper 77-1B, pp. 15-23.

Fullagar, P. D., \& Bottino, M. L. 1970. Rb-Sr Whole rock ages of Silurian-Devonian volcanics from Eastern Maine. Shorter Contributions to Maine Geology, 23, pp. 49-52.

Fyffe, L. R., Pickerill, R. K., \& Stringer, P. 1999. Stratigraphy, sedimentology and structure of the Oak Bay and Waweig formations, Mascarene Basin: implications for the paleotectonic evolution of southwestern New Brunswick. Atlantic Geology, 35, pp. 59-84.

Gates, O. 1975. Geologic map and cross sections of the Eastport quadrangle, Washington County, Maine. Maine Geological Survey Map Series, GM-3, 19 p., map.

Gates, O. 2001. Bedrock Geology of North Haven and Vinalhaven Islands. Maine Geological Survey Open-File Report 01-373, 28 p., map.

JaCKson, C. T. 1837. First report on the geology of the State of Maine. Smith and Robinson, Printers to the State, Augusta. $128 \mathrm{p}$.

Jackson, S. E., Guenther, D., \& Sylvester, P. J. 2003. Applications of laser-ablation ICP-MS analysis; a tribute to Henry P. Longerich. The Canadian Mineralogist, 41, pp. 257-365.

JURINSKI, J. 1990. Petrogenesis of the Moosehorn igneous complex, Maine, Unpublished M.S. thesis, Virginia Polytechnic Institute, Blacksburg, $125 \mathrm{p}$.

Kasper Jr., A. E., Gensel, P. G., Forbes, W. H., \& Andrews JR., H. N. 1988. Plant paleontology in the State of Maine: 
a review. In Studies in Maine Geology, Volume 1: Structure and Stratigraphy. Edited by R.D. Tucker \& R. G. Marvinney. Maine Geological Survey, Augusta, pp. 109-128.

Ludman, A., Hopeck, J. T., \& Brock, P. C. 1993. Nature of the Acadian orogeny in eastern Maine. In The Acadian Orogeny: Recent Studies in New England, Maritime Canada, and the Autochthonous Foreland. Edited by D. C. Roy \& J. W. Skehan. Geological Society of America Special Paper 275, pp. 67-84.

Martinsson, A. 1970. Correlation with Europe (ostracodes). In Correlation of North American Silurian Rocks. Edited by W. B. N. Berry \& A. J. Boucot. Geological Society of America Special Paper 102, pp. 41-49.

Martinsson, A. 1977. Palaeocope ostracodes. In The Silurian-Devonian boundary. Edited by A. Martinsson. International Union of Geological Sciences, Series A, No. 5, pp. 327-332.

Miller, B. V., \& Fyffe, L. R. 2002. Geochronology of the Letete and Waweig Formations, Mascarene Group, southwestern New Brunswick. Atlantic Geology, 38, pp. 29-36.

Newell, N. D. 1969. Systematic Descriptions - ?Eurymyella.In Treatise on Invertebrate Paleontology, Part N, Mollusca (Bivalvia). Edited by R. C. Moore. Geological Society of America and University of Kansas Press, Lawrence, p. N394.

Osberg, P. H., Tull, J. F., Robinson, P., Rudolph, H., \& Butler, J. R. 1989. The Acadian orogen. In The Appalachian-Ouachita Orogen in the United States. Edited by R. D. Hatcher Jr., W. A. Thomas \& G. W. Viele. The Geological Society of America, Boulder, Colorado, pp. 179-232.

Pickerill, R. K., \& Pajari Jr., G. E. 1976. The Eastport Formation (Lower Devonian) in the northern Passamaquoddy Bay area, southwest New Brunwick. Canadian Journal of Earth Sciences 13, pp. 266-270.

Shaler, N. S. 1886. Preliminary Report on the geology of the Cobscook Bay district, Maine. American Journal of Science, 3rd series, 32, pp. 35-60.
Siveter, D. J. 1989. Ostracodes. In A Global Standard for the Silurian System. Edited by C. H. Holland \& M. G. Bassett. National Museum of Wales, Cardiff, Wales, pp. 252-264.

Smith, G. O., \& White, D. 1905. The geology of the Perry Basin in southeastern Maine. U. S. Geological Survey Professional Paper, 35, $107 \mathrm{p}$.

Spooner, C. W., \& Fairbairn, H. W. 1970. Relation of radiometric age of granitic rocks near Calais, Maine to the time of the Acadian orogeny. Geological Society of America Bulletin, 81, pp. 3663-3670.

Sylvester, P. J. 2001. Laser-ablation-ICPMS in the earth sciences; principles and applications Mineralogical Association of Canada Short Course Series, St. John's, Newfoundland, 29, $243 \mathrm{p}$.

Tucker, R. D., Osberg, P. H., \& Berry, H. N. 2001. The geology of a part of Acadia and the nature of the Acadian Orogeny across Central and Eastern Maine. American Journal of Science 301, pp. 205-260.

VAN Wagoner, N. A., \& DAdD, K.A. 2003. A Silurian age for the Passamaquoddy Bay volcanic sequence in southwestern New Brunswick: implications for regional correlations. Geological Society of America Abstracts with Programs 35, No. 3, p. 79.

Williams, H. S. 1912a. Some new Mollusca from the Silurian formations of Washington County, Maine. Proceedings of the U. S. National Museum 42, pp. 381-398.

Williams, H. S. 1912b. Correlation of the Paleozoic faunas of the Eastport Quadrangle, Maine. Geological Society of America Bulletin, 23, pp. 349-356.

Williams, H. S. 1913. Correlation problems suggested by a study of fauna of the Eastport Quadrangle, Maine. Geological Society of America Bulletin, 24, pp. 377-398.

Editorial responsibility: Ron K. Pickerill 
